\title{
Integrating Africa by Competition and Market Policy
}

\author{
Eleanor M. Fox ${ }^{1} \mathbb{D}$
}

Accepted: 13 January 2022 / Published online: 2 March 2022

(C) The Author(s), under exclusive licence to Springer Science+Business Media, LLC, part of Springer Nature 2022

\begin{abstract}
Africa has the African Continental Free Trade Area (AfCFTA). The agreement will lower tariffs and facilitate internal market trade on the continent, and policy makers hope that it will help lift 30 million people out of poverty. A competition protocol is now in the process of negotiation and proposals have been made ranging from a full, detailed, technical competition law as in the West to a scaffolding of regional cooperation. For the competition element of AfCFTA, this article makes a bold suggestion: Africa needs a basic but deep competition protocol, which concentrates on the priorities "at the top": It needs to rid the continent of insidious trade-andcompetition restraints at member state borders that prevent African integration, which requires a joinder of trade-and-competition violations. And it needs a voice at the top to take a stand for the continent: for example against the mega-mergers that hurt Africa. Only with these three elements - clear basic rules, trade/competition restraint prohibitions, and a voice at the top - can Africa hope to realize the promise of Africa.
\end{abstract}

Keywords Africa - Trade ' Competition · Antitrust · Law and economics · Regulation - Globalization · Free trade agreements

Eleanor M. Fox

eleanor.fox@nyu.edu

1 New York University School of Law, New York, United States 


\section{Introduction}

Africa has a rare opportunity: It has adopted a continental free trade agreement: the AfCFTA. ${ }^{1}$ The Competition Protocol is due to be negotiated. Two alternative models are commonly suggested for the Competition Protocol: (1) a full continental antitrust law similar to the antitrust laws of most nations; or (2) intergovernmental cooperation with enhanced regionalism, which could possibly lead to a continental competition law.

This essay takes a different cut: Africa should create a bespoke architecture with few but critical functions at the center. It should also serve a coordinating role for the continent. Regionalism should proceed, but enforcement at the center cannot wait.

This essay offers a mode for considering what the center must do and ought not do, and then offers guidance on application of the principle. It addresses why the tasks at the center should be few and practicably achievable, and must be something more than and different from inter-governmental or regional cooperation.

I telescope here, at the outset, three major insights that argue for the "center core" model, and then proceed with a fuller argument on constructing the core:

1) A critical mass of the most egregious restraints on trade, competition and entrepreneurial creativity in Africa are hybrid; public and private conduct are intertwined. Many acts involve corruption by complicit officials and other abuses; these acts obstruct trade/competition at member state borders, and prevent Africa from functioning as an internal market. ${ }^{2}$ Africa has the opportunity to pioneer an integral trade/ competition regime that addresses the core of this central obstacle to the one-Africa vision. $^{3}$

2) Competition within Africa is increasingly regional or continental - not just national. African firms that were national champions - mostly owned by a few African political and business elites - are expanding across African state borders and competing with global firms in Africa. ${ }^{4}$ An effective competition law needs to have a geographical reach as wide as the competition that it is meant to address.

3) Africa needs a competition voice at the center, just as the European Union and the US each has a competition voice at the center. The central voice should speak to both internal-market (continent-wide) problems and global problems. Absent that

\footnotetext{
${ }^{1}$ The African Continental Free Trade Agreement (2019), entered into force for the first 24 countries on 30 May 2019. The agreement adopts many characteristics and clauses of both the World Trade Organization agreements and the European Union Treaties - while not contemplating the tight integration of Europe.

2 It is not intended to impugn nations' or regions' policies - open and transparent - to boost the capabilities of their people. This is policy space that nations and regions may legitimately claim - despite possible tradeoffs and debate. See, for examples of industrial policy that is designed to prime inclusive markets Andreoni, Mondliwa \& Tregenna (forthcoming); Roberts (2019a).

3 Trade law focuses on removing obstacles that are imposed by the state: including tariff and non-tariff barriers, such as regulations that are designed to protect domestic firms from the competition of outsiders. Competition law focuses principally on acts by private firms. The two types of restraints intertwine, but they are normally treated under different legal regimes, and the extent of their interaction is underappreciated. For an important paper that appreciates the intersection and highlights the critical importance of a seamless treatment of trade and competition restraints, see Sucker \& Klaaren (forthcoming).

${ }^{4}$ See Boso \& Adeleye (Jan/Feb. 2019). South African, Nigerian and Kenyan firms are leading the way. With thanks to Vellah Kedego Kigwiru for pointing me to this literature.
} 
voice, Africa will remain uncoordinated at home and a price-taker in the world. The developed world will continue to go first, setting the rules and foreseeing the outcomes with respect to all of the megamergers, world cartels, big tech abuses, and other global restraints that significantly impact Africa.

Background. Most of the member nations of AfCFTA and some of the many regional economic communities (RECs) have adopted modern competition lawsalthough many are not in force..$^{5}$ The competition laws that are in place and their execution are far from perfect, but a number of the nations and some RECs are developing their own competition ecosystems, which help to build capacity of the younger competition agencies and help align the national and regional systems. ${ }^{6}$

Crafting a coherent and effective continental competition law out of the current "spaghetti bowl" of national and regional authorities is a huge task. It would be hard for so many asymmetric nations to reach agreement on the terms-let alone to enforce the law in a meaningful way.

Setting up a system of voluntary coordination among the nations is not so hard; it is feasible. Substantial work is already being done in the Africa Competition Forum (which is like an African ICN). ${ }^{7}$ But the potential of nation-to-nation cooperation is limited and leaves critical tasks undone. Inter-governmental cooperation can do neither of the two most critical tasks that were identified above: drilling down on the business/state border restraints; and providing the platform at "the top" that is necessary for an economically unified Africa. Africa needs a more finely honed model.

In the search for this model, Europe offers a helpful principle: subsidiarity: ${ }^{8}$ What can be done as well or better at a lower level—national or regional—should be done at the lower level. The flip side is: Issues of essentially community level (here, the African continental community), which cannot be done as well at a lower level, should be done at the community level. I call this the "center core principle," which is the other side of the subsidiarity coin. Africa should sort out those issues that can be solved at a lower level ${ }^{9}$ and leave them at a lower level. It needs to identify those competition/market issues that cannot be solved well at a lower level, and weave them holistically into the central tasks of the AfCFTA.

This approach will go the longest, fastest way to creating a true African economic union. Failure to address the uniquely central issues will defeat the promise of Africa.

Thus, this essay asks: What important competition tasks can the lower level (national or regional) not do well or soon, or would probably not do at all? It looks in the space between the single-discipline silos (trade, competition, consumer protec-

\footnotetext{
5 See United Nations Economic Commission for Africa (2019) [“ARIA IX”]. See generally Fox \& Bakhoum (2019), especially Chapter 6. For a very helpful overview of the adoption, dimensions, and functionality of national and regional competition laws in Africa, see Büthe \& Kigwiru (2020).

${ }^{6}$ See Fox \& Bakhoum (2019), Chapter 6.

${ }^{7}$ Albeit with less extensive organization, participation, and work product. See Fox \& Bakhoum (2019) at 154-56.

${ }^{8}$ See Bermann (1994).

9 This essay does not consider the apportionment of tasks between national and regional bodies, which is a large separate issue and is the subject of significant on-going scholarship.
} 
tion), and it imagines a unifying notional "dome" at the top of the continent. ${ }^{10}$ Given its very particular focus, this essay does not dwell on important tasks at national and regional levels, which could start with enhanced intergovernmental cooperation and intensified capacity building within the RECs. It is expected that these projects would proceed side-by-side.

The essay proceeds as follows: Part I provides background on the AfCFTA and briefly describes proposals tabled for the Competition Protocol. Part II asks why the tasks at the top must be streamlined, and what are the competition/trade tasks that cannot be handled well at the lower level and must be addressed at the continental level. Part III provides examples of the issues that are identified in Part II. Part IV addresses the implications and applications of the suggested competences for AfCFTA. Part V concludes.

\section{Part I. Setting the Stage}

The growth and development of Africa over the last two decades was extraordinaryat least until the world financial crisis of 2008 and now the pandemic. The crises interrupted the narrative of Africa Rising. ${ }^{11}$ They not only closed some economic doors but widened the inequality gap both within the continent and comparatively with other continents. ${ }^{12}$ Africa's recovery and path forward depend in large part on its economic integration.

The African continent has a notoriously low level of intra-continental trade ${ }^{13}$ thanks to colonization and its vestiges. ${ }^{14}$ Economic integration depends on breaking out of the colonial path-dependence ruts, opening space for African innovation, and harnessing markets to work for Africa. If Africa can sufficiently free the forces of competition, increase the capabilities of its people, and control the market power that suppresses them, it not only will be able to prime the pumps of African production and innovation; it will also gain a voice in the world to help control the power of global corporations that are bigger than most nations, as well as call out and push back the trade restraints and other market imbalances that are repeatedly forced upon it. $^{15}$

These problems and potentials for a competition regime in Africa have been elaborated by scholars, research groups, and think tanks. The United Nations Economic Commission for Africa, with the African Union and UNCTAD, have published an important policy document: Next Steps for the African Continental Free Trade AreaAssessing Regional Integration in Africa, which proposes steps to build markets to

\footnotetext{
${ }^{10}$ Fox (2003a).

11 There are a few exceptions: Notably, Kenya and Tanzania appear to have recovered rapidly.

12 See United Nations Development Program (2020).

13 In 2013, intra-African trade was only $12 \%$ of total African trade; trade with Western Europe was $63 \%$. Kigwiru (2020). See also Gachuiri (2020); Hout \& Salih (2019); Ismail (2018).

${ }^{14} \mathrm{See}$, for the indelible effects of colonization on the Caribbean economy, Stewart (2020).

15 See note 59 infra.
} 
realize the potential of the AfCFTA. ${ }^{16}$ The United Nations Development Project has published: Africa's Promise: The UNDP Renewed Strategic Offer in Africa, which is a strategic plan to enable Africans to reach the continent's technological and human potential in sympathy with the Sustainable Development Goals. ${ }^{17}$

Other important contributions propose architecture for the AfCFTA Competition Protocol: Elizabeth Gachuiri's "Approaching Competition Policy in the AfCFTA"18 proposes a voluntary competition policy at the start, which would blossom into a mandatory regime. Vellah Kedogo Kigwiru's “The Cooperation on Competition Policy under the African Continental Free Trade Area" ${ }^{19}$ makes a range of proposals from a forum to strengthen national competition regimes, to addressing state interventions, to solving jurisdictional conflicts, to providing a research forum, to negotiating the substantive terms for a (soft) model law. Trudi Hartzenberg's "Cooperation on competition in the AfCFTA" 20 suggests nation-to-nation cooperation that is based on the competition chapter of the CPTPP (Comprehensive and Progressive Agreement of the Trans-Pacific Partnership), which requires that the parties have competition laws and specifies details for cooperation such as notifications, exchanges of information and training, and principles for procedural fairness. Kamala Dawar and George Lipimile's "Africa: Harmonising competition policy under the AfCFTA"21 urges developing and integrating competition regimes by continent-wide minimum standards, requiring market access, prohibiting transnational cartels and unjustified state trade-restraining acts, and implementing the principles through the RECs and member states. Jonathan Klaaren's "Increasing the benefits, reducing the costs"22 proposes development of regional competition principles where there are gaps in national regulation and where regional effects require a regional focus, as in value chains and cross-border mergers. ${ }^{23}$

The contemplated elimination of tariffs on intra-continental sales will have unevenly distributed costs on the various member states and will therefore pose challenges in negotiation. ${ }^{24}$

There are benefits and costs of all the proposals: A full competition law may be more than is needed and too ambitious and distracting to work. Intergovernmental cooperation is too unambitious to do the necessary work. Using the RECs as scaffolding en route to supporting a continental law is attractive and could work if the RECs were robust and reliable as sources of good law and institutions and good

\footnotetext{
$\overline{16}$ United Nations (2019), “ARIA IX."

${ }^{17}$ United Nations Development Program (2020), supra note 12, helpfully describes the beneficiaries of the SDGs "not as mere recipients of development assistance, but as valued hosts and development agents with inherent strengths and assets that can be strategically leveraged towards shared goals." p. 2. This, also, is a theme of Fox \& Bakhoum (2019), which develops the empowerment role of markets.

18 Gachuiri (2019).

19 Kigwiru (2020).

${ }^{20}$ Hartzenberg (2019).

21 Dawar \& Lipimile (2020).

22 Klaaren (2019).

${ }^{23}$ Klaaren proposes a mechanism to allocate matters to the appropriate authority. Klaaren (2021).

${ }^{24}$ Saygili, Peters \& Knebel (2018).
} 
cross-border enforcement; but most existing RECs are not in this position and are not likely to be so for a considerable time. ${ }^{25}$

\section{Part II. Why the Tasks at the Top Must be Streamlined, and What Must be Done at the Higher Level}

A first lesson comes from experience with attempts to devise a competition agenda within the World Trade Organization (WTO). In the 1990s, in view of the increasing frequency of global transactions and the synergies between trade law and competition law, a world competition code or framework seemed like the next logical step. It failed. While the quest for global coherence is not identical with the African project, in many ways the challenge of finding meaningful common ground among asymmetric countries is similar, and the experience with the construction and unravelling of a global competition agenda holds lessons for the AfCFTA.

What follows is a cautionary tale. Here is a simple caution: The more elaborate and complete the law, the less likely it is to be embraced by asymmetric nations unless it is voluntary only without enforcement teeth. If enforcement teeth are desired, a slim law that features the most essential prohibitions has a reasonable chance of success.

In the 1990s in the wake of globalization and appreciation of the depth and breadth of global economic issues, there was robust conversation about a global competition agenda for the world, which would be housed in the World Trade Organization (WTO). The WTO organized a Working Group on the Interaction between Trade and Competition Policy, which was chaired by Frédéric Jenny.

The European Union (EU) was the principal and most active proponent. The EU appointed a committee of "Wise Men." The Wise Men's Report ${ }^{26}$ articulated the need for a global vision in view of the global dimension of trade and competition. It proposed a modality: first, building blocks of cooperation, information sharing, and capacity building, with principles of nondiscrimination and due process; and working towards adoption of substantive principles for cross-border transactions (cartels, abuse of dominance). A framework for dispute settlement was to be largely dependent on member state cooperation in enforcement and the enforcement systems of the member states.

\footnotetext{
25 The East African Community (EAC) has virtually no enforcement record. The Common Market for Eastern and Southern Africa (COMESA) competition authority spends almost all of its enforcement time vetting mergers; it clears virtually all of them, and imposes conditions on only a few. It has begun to enforce prohibitions against cartels and monopolies. It does a great deal of policy work: educating and coordinating. The Southern African Development Community (SADC) is cooperative only. The Tripartite - comprising COMESA, EAC, and SADC - is in theory promising, since it covers a large territory (mostly accounted for by COMESA member states, some of which have overlapping memberships); it could be a sturdy steppingstone. WAEMU, in West Africa, has stripped competition enforcement powers from its member states, even for wholly internal competition problems: e.g., cartels with no cross-border effects. Senegal and other West African nations are embarked on an effort to get their powers back; but success is uncertain. See Fox \& Bakhoum (2019), Chapter 6, pp. 136-39; 145-53. For the significant on-going efforts to develop the competition dimension in the Tripartite, see Klaaren \& Sibanda (2019).

${ }^{26}$ Group of Experts (July 1995); Brittan \& Miert (1996).
} 
The WTO Working Group issued its own report and analysis: ${ }^{27}$ The report examined all the areas in which competition problems were intertwined with trade problems and where nations had incentives to impose costs on other nations, and it demonstrated how integration of the trade and competition problems could advance the cause of a freer, fairer, more efficient and more coherent global economic system. ${ }^{28}$

The EU refined its recommendations for competition rules in the WTO and circulated its proposal to its trading partners. In response, there was a split of the nations on the wisdom of a world competition agenda. Canada, Korea, and others supported the EU proposal. The US and developing countries opposed it.

The US argued that no high-level competition law was necessary; international competition policy could achieve what was needed with cooperation and extraterritorial jurisdiction. The US feared that substantive world principles would be too prohibitive and would handicap efficiencies; and it did not trust dispute resolution by unknown bureaucrats who (they imagined) either would lack technical competence or would protect small firms from the competition of efficient (American) firms.

Developing countries opposed the project for the opposite reason. They feared that a world competition law would replicate the free market stance of the West, which would deprive the developing countries of their policy space for industrial policies. ${ }^{29}$

The project for a global competition law or framework did not succeed. The European Union watered down its proposed agenda bit-by-bit in response to successive criticisms by the US. Ultimately it streamlined the proposal to narrow greatly the availability of dispute resolution - it would be available only to declare that a nation failed to adopt competition laws - and it withdrew all substantive provisions except a rule against hard-core cartels.

The reduced proposal was on the first agenda for the Ministerial Conference of the Doha Development Trade Round in 2001. However, the Doha negotiations on the most central trade issue (cotton subsidies) went badly when the US and the EU each failed to offer a package for reducing subsidies that was satisfactory to the developing countries, and the competition item was jettisoned from the trade round to clear the way for progress on the central trade issues. ${ }^{30}$

With the failure of the global competition initiative, what could be done? In the same year as the jettison of the global competition agenda, 15 competition agencies formed the International Competition Network (ICN) as a roots-up, voluntary organization that would work towards the convergence of national competition laws. ICN now has 140 members and is considered a great success in developing best practices of competition authorities in the world and increasing mutual understanding of national competition laws. By one point of view, ICN was a replacement for a world framework - and a better alternative - since nations would not need to relinquish

\footnotetext{
27 World Trade Organization (1998).

${ }^{28}$ See also Fox (1997).

${ }^{29}$ See Fox \& Crane (2017), pp. 615-25. Also, the developing countries argued that they lacked the readiness and technical capacity to negotiate the terms of such an agreement. Id.

${ }^{30}$ Id., pp. 625-26. Even that progress was never made. Id. The streamlined WTO competition agenda proposed by the EU, which substantively targeted only cross-border cartels, probably had a fair chance of adoption if not for the turn of events that: first, required that all attention be focused on trade subsidies; and, second, witnessed the growth of nationalism and nations' loss of appetite for freer global trade.
} 
sovereignty and the competition authorities could work together to achieve more coherence of their laws. By another perspective, ICN was a stepping stone for a global framework, which would seem more achievable as nations' laws converged. ${ }^{31}$

The view in the competition community that ICN eliminated the need for a global framework - which was strong-effectively meant that there was not going to be a global competition framework for the foreseeable future. What would that mean? Were the problems that led to the global discussions substantially addressed by horizontal cooperation of nations combined with extraterritorial reach of national law?

The questions led to consideration of the European subsidiarity principle: The issues that can be handled at a lower level should be handled at the lower level. Other competition principles are handled well at the national and nation-to-nation level. And what remains to be done- the serious competition problems that are not solved by nation-to-nation cooperation-would require multilateral efforts.

The list that evolved from this thought exercise ${ }^{32}$ is equally important for Africa, despite nuanced differences: As one example, nation-to-nation cooperation on competition laws, which are laws that control business restraints, misses the serious problem of national champions that persuade or pressure their governments to stem the tide of cross-border competition that would erode their power. For another, there are some problems that can be effectively understood only through a lens that is wide enough to reveal all harms of a conduct or transactions; as the saying goes, a blind person cannot appreciate an elephant by touching its foot.

For a third example: voice. Only with a voice "at the top" can competition (as a force, process, and discipline) be integrated with and not subordinated to trade, and can its relationship with industrial policy be appreciated; and, for the African continent, only with a voice at the top can Africa be a player and force to control megamergers and global conduct - some of which is relatively good for the developed world but bad for Africa.

Thus, it is helpful - if not critical-to ask: If the African national competition authorities, the RECs, and the African Competition Forum ${ }^{33}$ all do their work, what remains to be done at the top? These tasks must be vested in an AfCFTA authority, and we may wish to forbear assigning more, lest the vital tasks go undone.

The answer comes in four categories. The tasks that remain to be done are:

1) Law and its enforcement against hybrid (mixed public and private) border restraints: Vested interests continually combine with nationalism and statism to erect border barriers that fall between the cracks of competition law on the one hand and trade law on the other. The gaps persist in the names of both trade and sovereignty. ("This is not a competition problem," says the antitrust defendant; "and if it is, the state is my shield.") The breadth of these unjustified gaps is a big problem.

2) Vision from the "top" of the continent. This point has three branches: (a) Some market acts and transactions - such as megamergers - are truly of a continent-wide if not a world-wide dimension. Wise decisions would take account of all costs and benefits, wherever on the continent they fall. (b) Even if the issue appears to be only a

\footnotetext{
${ }^{31}$ See Fox (2011).

32 See Fox (2015).

33 See note 7 supra.
} 
two-country or one-region problem, political dynamics may require a higher authority to resolve it. (c) Overlaps in law stem from each nation's or region's own regulations, which produce over-regulation and inconsistent regulation.

3) Voice in the world: This category is about power and influence in the world; it is about the world hearing Africa. Some restraints are essentially global. The US and the EU have amplified voices in notional world governance. On competition issues, Africa has virtually no voice. The African voice can and should be influential in global competition policy on issues that significantly affect Africa. ${ }^{34}$ Africa needs a competition platform on which to speak.

4) Coordinating lower-level governance: A number of sectors-including food and agriculture, health, energy, telecommunications, banking/finance, and digital commerce-present market-related issues that can be handled at a regional level where regions have the capability, but need coordination. High-level task forces and think tanks can be constituted to study the field, consider the proper level for responsibilities, suggest high-level principles for policy, and monitor.

These four problems are urgent and cannot wait (long). They cannot wait for a complete competition law. Some are not even solvable by a complete competition law, and certainly not by nation-to-nation cooperation. The task now is to consider what needs to be done institutionally to meet the continental center-core challenges.

In some cases institutional scaffolding is in place. For state and private hybrid problems - which are rampant at African nations' borders - the AfCFTA basic agreement already includes provisions that are akin to European internal market $\operatorname{law}^{35}$ that prohibit undue state restraints that harm cross-border competition. This is a "freer movement" provision. ${ }^{36}$ If the freer-movement articles ${ }^{37}$ are integrated with competition law, and the law against hard-core hybrid restraints is enforced, border barriers

\footnotetext{
34 The importance of Africa's voice has several dimensions. For one, Africa makes a special contribution to substantive competition law. This can be seen especially in the laws of South Africa, which embed the value of inclusiveness and reject a paradigm that gives much weight to freedom of action of incumbents. This means that the scope for exclusionary practices is wider. See Fox (2017). Second, developed countries generally ignore harms to competition that fall outside of their borders. This is especially so when developed countries gain by developing countries' loss_- perhaps through the creation of buyer power. The Bayer/Monsanto merger is an example.

${ }^{35}$ Fox \& Healey (2014).

${ }^{36}$ In the European system, these are free movement provisions. I use "freer movement" to signify limits. See, for developing countries' need for limits on free trade, Ismail (2018), supra note 13. The provisions do not entail absolute free movement. Nations do not give up rights to regulate in the interests of their people, for example, for health, safety, and security.

37 Examples from European law include: Italy was not allowed to maintain a system that limited the volume of matches coming into Italy from German and Sweden; it could not order or authorize the Italian match producers to set quotas that discriminated against cross-border trade; and when the Italian match makers applied their quota-setting authority, granted by Italian law, to limit the Swedish and German producers, they were not protected or immunized from EU competition law by the fact that an Italian law gave them that authority. Case C-198/01 Consorzio Industrie Fiammiferi (CIF) v. Autorità Garante della Concorrenza e del Mercato, ECLI:EU:C:2003:430. See Fox (2003b). But Germany was allowed to adopt a law against predatory pricing that prevented low-priced coffee from coming across the border from France into Germany, so as to protect Germany's small businesses. Case C-267/91, Keck v. Mithouard, ECLI:EU:C:1993:905.
} 
will fall. ${ }^{38}$ If the fight against unjustified hybrid restraints succeeds, one of the biggest impediments to continental integration will be conquered. ${ }^{39}$

\section{Part III. Examples: Problems That Must be Solved at the Continental Level}

This part gives examples of problems that must be solved at the continental level.

1. Trade and competition, and hybrid public/private restraints

In this category are export cartels from one nation to another. It should not matter whether the cartel is private or intertwined with state approval. Also in this category are procurement restraints, which include bid-rigging. Bid-rigging conspiracies virtually always keep good suppliers from another nation out of the market. If bidrigging competitors and the corrupt officials who grease their wheels can be joined in one action, the enforcement will be more efficient and effective. Similarly, when a vested interest, which might be a single powerful producer, convinces customs officials to block competing goods from flowing across the border, this is a trade and competition problem.

A high-level gaze would be likely to produce rules that minimize state-action loopholes in competition law and private-action escape routes in trade law. ${ }^{40}$

2. Vision

a) Market-wide problems include cross-border cartels and megamergers

Cross-border cartels may escape detection. Data show a lack of trade flows from African countries with surpluses (e.g., in poultry, cement, fertilizer, or sugar) to neighboring countries with shortages. ${ }^{41}$ Why? A credible hypothesis is: private restraints, public restraints, or both. ${ }^{42}$ It should not matter which. Should these hybrid restraints be caught by the REC, if not by the national authority? Yes; but they are not being caught, even by RECs that have the tools in place. ${ }^{43}$ Moreover, the REC community may be insufficient in geographic scope. The countries involved may be members of different regional groupings. Or action at the continental center may be called for because the seemingly national or regional cartels are in fact run by the same co-conspirators across the continent. Or, simply, a large set of African countries

\footnotetext{
38 Jurisdictions all over the world - except the EU and China-have built competition law silos and trade law silos that obscure a major problem. Competition law is seen as catching private restraints, and trade law as catching public restraints. Strategic private actors play within the gap (hybrid restraints), where the most serious restraints occur. See Fox \& Healey (2014).

39 See Fox \& Bakhoum (2019), Chapter 6 and Conclusion. At the least, close cooperation and joint action between the competition and the internal market trade officials are needed.

40 The Chinese Vitamin C matter is the epitome of a successful strategy to play trade laws and competition laws against one another. The Chinese manufacturers had an export cartel into the United States. In the US antitrust case, the Chinese manufacturers argued that the Chinese Government ordered them to fix prices to the US; and the Chinese Government backed them up, averring that it had indeed so ordered. In the WTO action, China argued that the cartel was private action; that China had not ordered a cartel. China won-both times. See Fox (2019) (The facts were not quite so clear, but they clearly suggest this scenario).

${ }^{41}$ Roberts, Vilakzi \& Simbanegavi (2017); Roberts (2019b); Burke, Paramoer, Vilakazi \& Zengeni (2019).

42 See all authorities, note 41 supra.

43 See Fox \& Bakhoum (2019), describing merger control by COMESA., pp. 136-39.
} 
are involved. In all of these cases, enforcement at the center is more likely to appreciate the dimension of the problem and detect, punish, and deter. ${ }^{44}$

Megamergers that are of continental and even global dimension are a quintessential example of a need for pan-African vision. Cement is exhibit A: The cement industry is notorious for cartels. Virtually every country in the world with a competition law has prosecuted cement cartels. Cement cartels recur because of the inherent characteristics and incentives in the industry. Moreover, the cement industry is the most notorious vested interest that prevails upon governments to invoke anti-dumping laws to bar imports of lower-priced goods. ${ }^{45}$

The two leading cement companies in the world-Holcim and Lafarge-proposed to merge, which would create the largest cement producer globally and in Africa. The merging parties were active in 15 of the (then) 19 member states of the Common Market of Eastern and Southern Africa (COMESA).

The US cleared the merger with spinoffs to preserve competition in the US. The EU cleared the merger with spinoffs to preserve competition in Europe. Africa was left to fend for itself.

COMESA cleared the merger without conditions. It found no competition problems except in Mauritius, where the merger would produce monopoly, and sent the Mauritius aspects of the merger to Mauritius. ${ }^{46}$ Apart from Mauritius and Madagascar, these two leading cement producers in the world and in Africa did not do business in the African national markets of one another. Why? COMESA detected no competition problem except in Mauritius. It relied on the absence of overlap. It did not mention potential competition.

But weren't cross-border market-division cartels almost sure to be lurking in this cartel-endemic industry? ${ }^{47}$ Didn't the merger probably snuff out the most important potential competition in Africa? This merger was an excellent candidate for an absolute ban: in the US, in the EU, in Africa, and in the world. So too were the string of seed/fertilizer/chemical mergers, which were similarly cleared with conditions and spinoffs. $^{48}$

b) Higher-level suasion may be needed

Nations have nationalistic impulses. Vested interests trigger them. National firms may want to unleash their power to exploit cross-border buyers, against all principles of good competition and market integration. If the actors and victims are all in one

\footnotetext{
${ }^{44}$ Regional can be the right level, as well as a steppingstone to continental. See Klaaren \& Sibanda (2019); Roberts (2019b): "The examples of fertilizer and cement illustrate that cartel enforcement is very difficult at a national and even a regional level where the arrangements are international in nature." Id. at 181.

45 Most nations have enacted anti-dumping laws to prohibit trading partners from distorting their markets and destroying their home industries by exporting large quantities of below-cost or discriminatorily low-cost goods. These laws are often abused by powerful national producers who simply want to protect themselves from competition.

46 COMESA Competition Commission (2014). Commission Decision finding that "the merger does not raise competition concerns" in the common market and referring the Mauritius part to Mauritius. See Fox \& Bakhoum (2019), pp. 137-38.

47 See Sucker \& Klaaren (forthcoming), notes 136-140; Roberts (2019b), pp. 179-81; Roberts, Vilakazi \& Simbanegavi (2017), at 276.

48 See Mooney (2017) [“Too Big to Feed”].
} 
region, regional antitrust might seem exactly the right level to defang the violators; but experience shows that, left to their own devices (and power) within the region, the big actors might prevail. A higher-level task master might be necessary, to defend competition in the region and the larger community.

Our example here involves restraints in Mexico that affected US telecom service providers that were reliant on Mexican telecoms to receive and re-transmit the signal, Mexican consumers, and a regional free trade agreement: the North American Free Trade Agreement (NAFTA).

In Mexico, the telecommunications industry was substantially owned by Carlos Slim, then the richest man in the world and friend and patron of Mexican presidents. Telephone prices in Mexico were the highest in the world.

Many Mexicans emigrated to the United States to find work. They would send remittances to their families. They wanted to talk with their loved ones, but the price of telephone calls from the US to Mexico was exorbitant. Why? The Mexican regulatory agency enabled the market power of the Mexican industry. Mexico's agency adopted regulations that required all Mexican telecom companies to match the price of the largest carrier, which was Slim's Telmex. The Mexican companies were happy to comply.

AT\&T complained to the WTO for Mexico's violation of the rules of the GATS and the Telecom Reference Paper. ${ }^{49}$ Under the Reference Paper, Mexico had agreed to maintain and enforce its competition laws. A WTO panel declared that Mexico was in breach of its Reference Paper obligations by ordering a cartel. ${ }^{50}$ This is an excellent example of a hybrid restraint, successfully attacked by resort to higher law.

Why didn't AT\&T seek relief under its regional agreement? NAFTA was weak. Its competition provisions were only precatory. A framework for more meaningful seamless competition for North America had been proposed but rejected, in the name of sovereignty. ${ }^{51}$ The successor US/Canada/Mexico FTA (2020) carries forward the same limitations. African REC agreements have similar limitations. Only a higher authority may have the gravitas to do the job.

c) Overlap and overregulation

In matters of overlap and over-regulation, pre-merger notification regimes are the paradigm example. Scores of countries vet the same merger, even when the effects in the reviewing jurisdictions are likely to be the same. This is wasteful. ${ }^{52}$ It is particularly wasteful in Africa, with so many small economies and such scarcity of human

\footnotetext{
49 WTO (1996).

${ }^{50}$ Fox (2006). Among other things, Mexico made an industrial-policy defense: that the Mexican telecoms companies needed the monopoly revenues to provide service to the unserved poorest parts of Mexico. However, the Mexican telecom companies did not use the extra revenues to serve the poorest parts of Mexico, which remained unserved.

51 The parties even refused to relax the cross-border anti-dumping laws and to refrain from export cartels solely within the free trade area (although Canada would have agreed). Fox \& Crane (2017), pp. 606-07. The competition authorities of the United States, Canada, and Mexico coordinate deeply, bi-laterally, pursuant to memoranda of understanding, not NAFTA. For proposals from the American Bar Association Antitrust Section, NAFTA Task Force, see ABAAS (1998).

52 See excerpts from Eleanor Fox's concurrence in The International Competition Policy Advisory Committee (ICPAC) Report (2000), reprinted as Appendix A to Fox (2015), supra note 32.
} 
and financial capital, ${ }^{53}$ despite the fact that $95 \%$ of filed mergers present no competition problem. The unnecessary overlap is costly both for the competition authorities and for the filing firms.

Dawar and Lipimile propose that countries should agree at the least to accept premerger filings that have been prepared for the African jurisdiction of first filing, and require supplements as necessary to account for specific market facts. ${ }^{54}$ A continental pre-merger notification clearing house ${ }^{55}$ would be a great improvement.

3) Voice

Africa needs voice. It needs a competition platform from which to speak. ${ }^{56}$

Imagine the European Union without the Competition Commissioner. Imagine all of the European member states with their own 27 competition laws, no EU competition law, and only a coordination function to fill gaps and smooth inconsistencies.

If the African continent had an African competition policy at the time that Holcim and Lafarge announced their merger, and similarly for other megamergers that significantly affected the Africa continent — such as Bayer/Monsanto ${ }^{57}$ — an African Competition Commissioner might well have convinced the other interested authorities of the world to forsake their conservatism and (each) enjoin the merger; and with the coordinated winds behind the African Commissioner, he or she could credibly do so too. When the gaze is lifted to the world, one can see clearly that world competition would be better off without significantly anticompetitive megamergers. ${ }^{58}$ Also, if the African continent had a trade and competition platform, the African Trade Commissioner along with the African Competition Commissioner might gain the extra strength of voice to call out the global trade and competition restraints that disproportionately hurt the African continent, and obtain for Africa a fairer (as well as more efficient) deal. ${ }^{59}$

\footnotetext{
53 The African nations' competition authorities (apart from French West Africa, which has no merger control) spend the large majority of their time vetting mergers, at the expense of other priorities. See Fox \& Bakhoum (2019) at 89.

54 See Dawar and Lipimile (2020).

55 See Fox (2015), supra note 52.

56 See Fox \& Bakhoum (2019) at 201-02; Klaaren (2021); Kigwiru (2020).

57 Megamergers not uncommonly create buyer power against suppliers in developing countries. Bayer Monsanto was such a merger. These harms are not of interest to and totally disregarded by the developed world. See, for analysis of the integral harms, Mooney (2017) “Too Big to Feed," supra note 48.

58 The question in these cases is not whether the merger was significantly anticompetitive but what should be the remedy. Why should the merger not be enjoined? Is it fine for the mature jurisdictions simply to order spinoffs that protect their countries-where the home countries realize some gains from the newly created market power, the worst anticompetitive effects are in developing countries, and the developing countries have no practical power to stop the merger?

59 The West tends to raise the costs of or squeeze the suppliers in developing countries and at the same time narrow markets for exports from developing to developed countries. See Wolf (2005). Western countries have facilitated fertilizer export cartels, harming African farmers, while funneling subsidies to their own cotton producers, who use them to outcompete lower-cost African cotton. See New York Times (2003).In every field of life and trade, countries with power tend to take strategic advantage of the poorest and most vulnerable, giving developing nations a Sisyphean task to perform well economically. See, e.g., Wallerstein (1974). Moreover, vested interests - whether domestic or foreign — tend to manipulate the structure of the economy to their advantage, embedding and continually exacerbating inequality. See Goga, Mondliwa \& Simon Roberts (2020).
} 


\section{4) Coordination}

A prime example that falls within the coordination role for the center is big tech/ big data. The big tech platforms, while offering opportunity to entrepreneurs, have substantial market power that is bolstered by unprecedented network effects, and they use it. They entrench their platforms, building barriers even higher. They launch their own businesses on the platforms that they host — often copying the pioneers that were there first - and they squelch their rivals on the platform at will, chilling African entrepreneurship and undermining African innovation. They appropriate the data of rivals, deny access by rivals to the data that are necessary to compete, and violate laws of data protection/privacy and consumer protection. ${ }^{60}$ Authorities all over the world - including South Africa - have authored studies or adopted or are considering regulation.

What are the needs of Africa? Is there a common position? A high-level task force, combined with a research team, should address these questions. The group would consider the special needs of Africans for access to the dominant platforms without fear of predation by the gatekeepers. It would consider how Africa can take advantage of rules and codes of conduct that have been promulgated by other jurisdictions, as the European Union is poised to do. ${ }^{61}$

The coordination function can have a variable geometry. In some cases, regional authorities can do the job if they have the capacity and will. Even so, good regulation would entail coordination from the center. Jonathan Klaaren identifies several areas for regional- rather than national-level policy, such as: energy systems, value chains, and procurement. ${ }^{62}$ Expert task forces at the continental level could identify the best level of regulation and provide for coordination and coherence, and modes for avoiding overlaps, avoiding over-regulation, and filling the gaps.

\section{Part IV. Implications and Implementation-Proposed Priorities}

The stories and analyses above hold lessons for Africa. The AfCFTA competition/ market law should be molded to the priorities. Here are proposed priorities for consideration:

1. For enforcement

a. Cross-border hard-core cartels, with priority given to cartels that involve a critical mass of African countries

Cross-border cartels of African dimension must be a major subject for enforcement at the center. An expert task force can first determine if identified cartels are

\footnotetext{
${ }^{60}$ United States House of Representatives (2020).

61 See European Commission (2020); Fox \& First (2020).

62 See Klaaren (2021); Montmasson-Clair \& Deonarain (2019). Research teams at CCRED, of the University of Johannesburg, South Africa, advance the idea of regional integration that includes regional value chains as a promising way to build African capabilities - especially in view of recent exclusions from global value chains in the wake of the coronavirus pandemic. See Roberts (2019a).
} 
essentially continental or regional. ${ }^{63}$ If the former, enforcement at the center should proceed. Central enforcement is especially important against cartels that balkanize African nations or regions ${ }^{64}$ and thus frustrate African integration. It is especially important to focus on cartels of African producers even more than world cartels (such as in vitamins, air cargo, and foreign exchange), because cartels of African producers are more likely to balkanize Africa and only Africa will right this increasingly common wrong. Also important is enforcement against world cartels that significantly harm Africans, who, just like developed world victims, should be compensated. ${ }^{65}$

Since many cartels - especially the most stable ones-involve state action and sometimes rogue state officials, effective enforcement requires common work with the AfCFTA officials who are in charge of the internal market (freer movement), and sometimes with national prosecutors.

This enforcement should become active soon after the Competition Protocol is effective - while there is momentum - lest the law languish on the books. At least in the early stages of enforcement, experts from African nations and from all over the world should be deputized. Experts are likely to welcome the opportunity to lend their expertise to help "jump-start" competition enforcement for the continent.

b. Mergers

i. Megamergers with significant African effects

A merger unit should be formed within the Competition Commission to analyze the effects of global mergers that are likely to have significant effects in Africa. The unit can be small at first, with a view to deputizing highly experienced experts from national competition authorities with expertise, on the relatively few occasions when megamergers must be vetted. The team should consult and coordinate with other major authorities in the world that are simultaneously analyzing the same proposed merger. The analysts should consider the world market as well as Africa.

Upon a determination that a global merger has significant anticompetitive effects in Africa-after considering efficiencies, innovation incentives, and technological improvements likely to be realized for Africa - the Competition Commissioner, with support of the head of AfCFTA, should coordinate with the major antitrust enforcers in the world in an attempt to reach consensus on treatment. Prohibition should be the preferred remedy.

Effectiveness of this proposal, combined with premerger notification (see immediately below), depends on the political willingness of the African nations to pool their sovereignty for the good of the African community. Politically, this may be difficult to accomplish, but regard for the continental community above national interestsnotably, receiving merger filing fees - is absolutely necessary to make Africa work. ${ }^{66}$

\footnotetext{
${ }^{63}$ The COMESA Competition Commission and the World Bank are cooperating on a project to identify cross-border cartels within the COMESA common market, with a view to COMESA's prosecution of offenders. Perhaps the project will uncover both cartels within the COMESA region and cartels that span regional borders. The findings may be useful in considering the most appropriate level for enforcement.

${ }^{64}$ As noted earlier, supra note 4, a number of firms that are dominant in African nations have expanded beyond national borders. They may be carving out spheres of influence in Africa.

${ }^{65}$ Africa may be able to enjoy the benefits of international enforcement against world cartels.

${ }^{66}$ This was an issue in COMESA on the activation of COMESA merger control-which was ultimately resolved with an agreement with respect to the sharing of fees. The chance to get merger filing fees creates
} 


\section{ii. Premerger notification process: an African Clearing House}

Africa, at the center, needs a premerger notification clearing house. The clearing house would receive all first-instance filings in Africa of mergers with significant cross-border effects. The African continental merger group should develop a form for first filings. Parties would be required to specify where in Africa the effects are most likely to be felt- by countries and by regions - and to specify premerger and postmerger market shares in Africa and in any geographic market in or including Africa.

African RECs and countries of impact may consider follow-on requests for more information, after coordinating through a Continental Competition Network (CCN) that is modeled after the European member state network-ECN (European Competition Network) and COMESA's own COMESA Competition Network. Note must be taken of the many African regions and nations that do not have merger-vetting capabilities. (There are no merger control laws in French West Africa.) A task force at the continental level should advise on modes of devolution and how to take account of the lack of capacities at lower levels.

\section{c. Anticompetitive agreements other than hard-core cartels}

The AfCFTA Competition Commission should focus on the most harmful agreements with the most continent-wide effects - especially restraints that balkanize Africa. A good object of surveillance is trade associations - especially where the same companies are players in trade associations in a number of African countries or regions. Trade associations are often fora for standard-setting (as well as for naked cartels), and the standards that they set often have the design or at least the effect to exclude new entrants from "the club." ${ }^{, 67}$ The trade association may have put forth arguments, sometimes credible, that it was trying to protect safety and quality, ${ }^{68}$ and their contentions need to be assessed. A task force or research group should ferret out the continental problems, monitor them, and propose AfCFTA proceedings where warranted, and should be a center for acquiring knowledge and information from regional and national networks and formulating modes for devolution.

The AfCFTA Competition Commission should be alert to situations in which government officials are complicit, or where state action including excessive regulation

\footnotetext{
perverse incentives; nations have no inherent right to them; and the opportunity for them creates bad incentives to expand premerger filing requirements even when the information is not needed for any good policy reason. But many nations have become accustomed to receiving large fees and to using the fees to fund their agencies, and it is hard to give up this easy source of revenue. See Büthe \& Kigwiru (2020), supra note 5 , identifying African countries' resistance to relinquishing sovereignty especially over megamergers as a major challenge to integration of Africa. Id. at pp. 61-68.

${ }^{67}$ See Allied Tube \& Conduit Corp. v. Indiana Head, Inc., 486 U.S. 492 (1988). For more on the uses of power of incumbents, see Mooney (2017), "Too Big to Feed," supra note 48, and the authorities that are cited in note 59, supra.

${ }^{68}$ See Competition Commission and Tracetec v. Netstar, 17 CR/Mar05 (Competition Tribunal 2010), rev'd, Netstar (Pty) Ltd v. Competition Commission South Africa and Another (99/CAC/MAY10, 98/ CAC/MAY10, 97/CAC/MAY10) [2011] ZACAC 1; 2011 (3) SA 171 (CAC) (15 February 2011). See Fox \& Bakhoum (2019), Chapter 5: South Africa: Leaning in Towards Inclusive Development, highlighting the seriousness of the trade association restraint, which was a Catch 22 to keep out new entrants. Pp. 101-03, 115. Compare Case C-120/78 Rewe-Zentral AG v. Bundesmonopolverwaltung für Branntwein (Cassis de Dijon), ECLI:EU:C:1979:42 (custom and standards that would keep foreign brandy out of Germany).
} 
has serious anticompetitive effects, and should prioritize enforcement against intertwined state and private restraints. ${ }^{69}$

d. Abuse of dominance or of significant market power

Abuse of dominance should generally not be an area of enforcement except when a leading firm conspires with a government official to impose a serious cross-border restraint, or where action by an SOE or the exercise of state-granted privileges, perhaps in procurement, tends to balkanize Africa. Teamwork between the competition officials and the freer-trade-movement officials is essential.

While not foreseen immediately, AfCFTA can take a page from the WTO playbook and recognize that telecommunications restraints are a global [read African] problem and need global [African] governance. Provisions similar to the WTO Telecoms Reference Paper ${ }^{70}$ could be considered.

2. Policy other than enforcement

A major part of the work of the AfCFTA Competition Commission must be at the level of policy other than enforcement. It would be misleading to call this work "competition advocacy," which is a phrase that has been transplanted from the United States where advocacy by the competition authorities before other agencies or the legislature is an adjunct to the main tasks of the authorities. In Africa, this is major task force/think tank work.

The continental Competition Commission should do a scoping project, which would develop a broad view of the market-obstruction problems in Africa. It should develop methodologies and proposals for identifying problems that should be handled at the continental level and what is needed to handle them; and how to enhance capabilities in regional competencies of the RECs.

While covered in part above, examples of problem areas that are likely to need such attention are: continental value chains; special sectors such as big tech/big data and other online commerce; telecoms; energy; agriculture; retail; and finance, including access to money transfers and access to business funding. Challenges that need study include: how to link industrial policy; how to coordinate regulation with antitrust; and in general how to unleash innovation incentives of the African population and create an unobstructed playing field for African competition on the merits. A research team can be assembled within the AfCFTA, and can draw upon assistance from and partnership with the African Development Bank, the World Bank Group, REC officials, and research groups such as CCRED at the University of Johannesburg. ${ }^{71}$

\section{Part V. Conclusion}

From the foregoing analysis we can draw some conclusions about what Africa needs to do at the center core, and what should devolve under the principle of subsidiarity. Here is one view of what Africa needs to do and not do at the center:

\footnotetext{
${ }^{69}$ See Fox \& Healey (2014), supra note 35.

70 Supra note 49.

71 See, as an example of the excellent work that has emanated from CCRED, Vilakazi, Goga \& Roberts (2020).
} 
At the center, within AfCFTA, the policymakers should:

1. Create a Competition/Market Commission, which should be directly linked with the Internal Market Commission ${ }^{72}$ and also seamlessly linked with counterpart issues of consumer protection so that problems can be solved holistically. Authorities should appoint a forceful, proactive Commissioner in charge of the Competition/Market portfolio. The competition mandate should be streamlined. Policy and enforcement action should be initiated almost immediately after the Competition Protocol is adopted and the directorate is staffed. The competition program adopted should be manageable, credible, and with bite.

2. Adopt a provision that specifies and limits the scope of jurisdiction for enforcement. The provisions should have regard for the size and place of effects on commerce in Africa and the thresholds for intervention.

3. Adopt a law against cartels with significant cross-border aspects-including cartels that are facilitated by state acts. ${ }^{73}$

4. Adopt a parallel provision for unilateral private action that is linked with action by government officials (this could include bribery and procurement corruption) that targets cross-border restraints.

5. Establish a premerger notification clearing house.

6. Adopt a provision to declare unlawful anticompetitive megamergers with significant African effects, and confer the power to enjoin.

7. Monitor restraints of continental dimension to verify that the above categorization catches all significant restraints that threaten African integration.

8. Establish high-level task forces to address specific sectors and problems, such as in: Big Tech; energy; banking/finance; communications, including telecoms; online commerce; supermarkets; general retail; and supply chains. A supra-coordinating task force should consider the proper level of regulation and devolution.

9. Facilitate the work of the African Competition Forum in coordination, collaboration, and capacity-building among African nations' competition authorities. ${ }^{74}$

The slim and focused law should be good for all Africans - regardless of the state of their country's development. All Africans should be winners, not losers, except vested interests and corrupt players; enforcement should further the values of fairness and inclusiveness. ${ }^{75}$ Further applications of fairness, inclusiveness, and other public interests would remain entrusted to lower levels - the regions and the member states.

\footnotetext{
72 Consider how considerable progress was made and creative cross-discipline thinking advanced in the European Union (then the European Community) when Karel von Miert was Commissioner for Competition and Sir Leon Brittan, having been Commissioner for Competition, was Commissioner for Trade and for External Affairs; and when in the United States Carla Hills, who had been Chair of the US American Bar Association Antitrust Law Section, became United States Trade Representative, and James Rill, also a past chair of the ABA Antitrust Law Section, was Assistant Attorney General for Antitrust.

73 "State acts" refers to unjustified state acts, such as those that are the product of vested interests. This is a very large subject, which is not fleshed out in this article. It is intended that the suggested proposal not interfere with legitimate regulation such as for health and safety (which ordinarily would not require a cartel in any event).

74 While at some point this function might be folded into the AfCFTA competition authority, this task of coordination, cooperation, information-sharing, and capacity-building is huge and needs to be done at the grass roots without bureaucracy. The momentum is now at grass-roots level.

75 Inclusiveness is a value that should be embedded in the substantive law. See Fox (2017), supra note 34.
} 
Thus, it should not be necessary to engage beforehand with issues of how to include fairness, inclusiveness, disparate bargaining power, and public interests. ${ }^{76,77}$

What not to do at the center: Filter out and do not handle at the center what can be done well at a lower level.

A reprise on goals. The goal is to integrate Africa by making markets work for Africa, thus eliminating both public and private restraints that (at least in most cases) have no reason for existing other than to enrich the perpetrators on the backs of the people. The corollary goal is to provide a platform for the voice of Africa on trade/ competition/market issues. The slim and focused enforcement that is proposed here should benefit Africans as consumers and business people, increase the efficiency of African markets and the competitiveness of African business, and clear the path for and thus empower African entrepreneurs.

In conclusion, to make significant progress in African integration, Africa needs to adopt and implement trade-and-competition policy, and selective competition policy, at the continental level. It needs a sharp and early focus on the special problems of its mission, which fall into the categories of trade and competition, vision, and voice. It needs to integrate policies above the single-discipline silos of technocratic expertise in order to de-balkanize Africa.

Fortuitously, the AfCFTA provides a platform to so do.

Acknowledgements Eleanor Fox is Walter J. Derenberg Professor of Trade Regulation, New York University School of Law. She thanks Vellah Kedogo Kigwiru, Jonathan Klaaren, George Lipimile, Simon Roberts, and Thomas Ross for their very helpful comments, and she thanks her research assistant, Edmund Brose, JD Candidate, NYU Law Class of 2023 for his excellent research assistance.

\section{References}

Andreoni, A., Mondliwa, P., Roberts, S., \& Tregenna, F. (Eds.). (forthcoming). Structural transformation in South Africa: The challenges of inclusive industrial development in a middle-income country. Oxford University Press

African Continental Free Trade Agreement. (2019). Retrieved November 4, 2021, from tralac.org

Allied Tube \& Conduit Corp. v. Indiana Head, Inc. (1988). 486 U.S. 492

American Bar Association Antitrust Section. (1998). Report of the task force of the Aba section of Antitrust Law on the competition dimension of Nafta

Bermann, G. A. (1994). Taking subsidiarity seriously: Federalism in the European Community and the United States. Columbia Law Review, 94, 331

Boso, N., \& Adeleye, I. (Jan/Feb. 2019). The internationalization of African firms: Opportunities, challenges, and risks. Thunderbird International Business Review, 1(61)

Brittan, L., \& v. Miert, K. (1996). Communication (96) 284 submitted by Sir Leon Brittan and Karel van Miert towards aninternational framework of competition rules. Communication to the Council

\footnotetext{
76 See Ismail (2018), supra note 13, for the importance of preserving the values and policy space of the people.

77 There are many issues that are not addressed in this essay. For example: Relief and remedies-Available remedies should be strong enough to deter. Victims should get recompense, either through direct actions or fines that include private harms, with monies to be distributed. Independence: Independence from political pressures and cronyistic demands should be assured. Systems of enforcement and appeals, including due process, must be constructed. This essay is not a blueprint. It is meant to launch an idea for the general character of the competition system within AfCFTA.
} 
Burke, M., Paramoer, T., Vilakazi, T., \& Zengeni, T. (2019). Building institutions for competition enforcement and regionalintegration in Southern Africa, conclusion. In J. Klaaren, S. Roberts, \& I. Valodia (Eds.), Competition and inclusive growth in Southern Africa (pp. 487-528, 492). Jacana

Büthe, T., \& Kigwiru, V. K. (2020). The spread of competition law and policy in Africa: A research agenda. African Journal of International Economic Law (AfJIEL). Retrieved November 4, 2021, from afronomicslaw.org

Case C-120/78 Rewe-Zentral AG v. Bundesmonopolverwaltung für Branntwein (Cassis de Dijon), ECLI:EU:C:1979:42

Case C-267/91, Keck v. Mithouard, ECLI:EU:C:1993:905

Case C-198/01 Consorzio Industrie Fiammiferi (CIF) v. Autorità Garante della Concorrenza e del Mercato, ECLI:EU:C:2003:430

COMESA Competition Commission. (2014). Staff paper no. 2014/12/LL/01, to the committee of initial determination regarding the notification of the proposed merger between Holcim limited and Lafarge S.A. Retrieved November 4, 2021 https:/www.comesacompetition.org/wpcontent/uploads/2014/10/ Decision-Holcim-and-Lafarge.pdf

Competition Commission and Tracetec v. Netstar, 17 CR/Mar05 (Competition Tribunal 2010), rev'd, Netstar (Pty) Ltd v. Competition Commission South Africa and Another (99/CAC/MAY10, 98/CAC/ MAY10, 97/CAC/MAY10) [2011] ZACAC 1; 2011 (3) SA 171 (CAC) (15 February 2011)

Dawar, K., \& Lipimile, G. (2020). Africa: Harmonising competition policy under the AfCFTA. Concurrences No. 2-2020, 242, para. 30

European Commission. (2020). Press release, 15 December 2020, Brussels, Europe fit for the digital age: Commission proposes new rules for digital platforms. Retrieved November 4, 2021, from https:// ec.europa.eu/commission/presscorner/detail/en/ip_20_2347

Fox, E. M. (1997). Toward world antitrust and market access. The American Journal of International Law, 91(1)

Fox, E. M. (2003a). International antitrust and the Doha Dome. The Virginia Journal of International Law, 43,911

Fox, E. M. (2003b). State action in comparative context: What if. In B. Hawk (Ed.), 2003 Fordham corporate law institute: International antitrust law \& Policy (p. 463). Juris Publishing

Fox, E. M. (2006). The WTO's first antitrust case-Mexican telecom: A sleeping victory for trade and competition. Journal of International Economic Law, 9, 271

Fox, E. M. (2011). Linked-in: Antitrust and the virtues of a virtual network. In P. Lugard (Ed.), International competition network (p. 10). Cambridge University Press

Fox, E. M. (2015). Antitrust without Borders: From roots to codes to networks. E15 expert group on competition policy and the trade system. Retrieved November 4, 2021, from http:/e15initiative.org/ wp-content/uploads/2015/09/E15-Competition-Fox-FINAL.pdf

Fox, E. M. (2017). Outsider antitrust: 'Making markets work for people' as a post-millennium development goal. In T. Bonakele, E. Fox, \& L. Mncube (Eds.), Competition policy for the new era: Insights from the BRICS countries (Chapter 2). Oxford University Press

Fox, E. M. (2019). Antitrust and the clash of sovereigns-Bringing under one roof: Extraterritoriality, industrial olicy, foreign sovereign compulsion, and (bad) applications of law against 'my country's' firms. Concurrences N 4-2019, 73-81

Fox, E. M., \& Bakhoum, M. (2019). Making markets work for Africa: Markets, development, and competition law in Sub-Saharan Africa. Oxford University Press

Fox, E. M., \& Crane, D. A. (2017). Global issues in antitrust and competition law. 2d ed. West

Fox, E. M., \& First, H. (2020). We need rules to rein in big tech. Competition policy international. Retrieved November 4, 2021, from https://www.competitionpolicyinternational.com/ we-need-rules-to-rein-in-big-tech/

Fox, E. M., \& Healey, D. (2014). When the state harms competition - the role for competition law. Antitrust Law Journal, 79, 769

Gachuiri, E. (2019). Approaching competition policy in the AfCFTA. In Luke, D. \& MacLeod, J. (Eds.), Inclusive trade in Africa: The African continental free trade area in comparative perspective. Routledge

Gachuiri, E. (2020). African continental free trade area phase II negotiations: A space for competition protocol? UNCTAD Research Paper No. 56. Retrieved November 4, 2021, from https:/unctad.org/ webflyer/african-continental-free-trade-area-phase-ii-negotiations-space-competition-protocol 
Goga, S., Mondliwa, P., \& Roberts, S. (2020). Economic power and regulation: The political economy of metals, machinery and equipment industries in South Africa. In D. Francis, I. Valodia, \& E. Webster (Eds.), Inequality studies from the global south. Routledge

Group of Experts. (1995). Report, competition policy in the new trade order: Strengthening international cooperation and rules established by competition commissioner van Miert

Hartzenberg, T. (2019). Cooperation on competition in the AfCFTA. Tralac Blog. Retrieved November 4, 2021 from https:/www.tralac.org/blog/article/14078-cooperation-on-competition-in-the-afcfta.html

Hout, W., \& Salih, M. A. M. (2019). A political economy of African regionalisms. Edward Elgar Publishing

Ismail, F. (2018). A 'Developmental regionalism' approach to the AfCFTA. In celebration of the 90th birthday of Chief Olu Akinkugbe CFR CON. Retrieved on November 4, 2021 from https://www.tips.org.za/research-archive/trade-and-industry/ item/3542-working-paper-a-developmental-regionalism-approach-to-the-afcfta

Wallerstein, I. (1974). The modern world-system II. Academic Press

Kigwiru, V. K. (2020). The cooperation on competition policy under the African continental free trade area. Manchester Journal of International Economic Law, 17(18), 98, 100

Klaaren, J. (2019). Increasing the benefits, reducing the costs. Symposium, plurality of law and development. Retrieved November 4, 2021, from https://voelkerrechtsblog.org/ increasing-the-benefits-reducing-the-costs/

Klaaren, J. (2021). The emergence of regulatory capitalism in Africa. Economy \& Society, 50(1)

Klaaren, J., \& Sibanda, F. (2019). Competition policy for the Tripartite free trade area. In J. Klaaren, S. Roberts, \& I. Valodia (Eds.), Competition and regulation for inclusive growth in Southern Africa (p. 59). Jacana

Montmasson-Clair, G., \& Deonarain, B. (2019). Regional integration in southern Africa: A platform for electricity sustainability. In J. Klaaren, S. Roberts \& I. Valodia (Eds.), Competition and regulation for inclusive growth in Southern Africa (p. 487). Jacana

Mooney, P. (2017). Too big to feed: Exploring the impacts of mega-mergers, consolidation and concentration of power in the agri-food sector. iPES Food. Retrieved November 4, 2021, from http://www. ipes-food.org/ img/upload/files/Concentration_FullReport.pdf

New York Times. (2003). Harvesting poverty. Retrieved November 4, 2021, from https://archive.nytimes. com/www.nytimes.com/ref/opinion/harvesting-poverty.html?page

Roberts, S. (2019a). (Re)Shaping markets for inclusive economic activity: Competition and industrial policies relating to food production in Southern Africa. In R. Kanbur, A. Noman, \& J. E. Stiglitz (Eds.), The quality of growth in Africa (Chapter 10). Columbia University Press

Roberts, S. (2019b). Common law prescriptions and competitive outcomes: Insights from Southern and East Africa. In D. Gerard, \& I. Lianos (Eds.), Reconciling efficiency and equity: A global challenge for competition policy. Cambridge University Press

Roberts, S., Vilakzi, T., \& Simbanegavi, W. (2017). Competition, regional integration and inclusive growth in Africa: A research agenda. In J. Klaaren, S. Roberts, \& I. Valodia (Eds.), Competition law and economic regulation: Addressing market power in Southern Africa (pp. 263-87). Wits University Press. http://oapen.org/search?identifier=634572

Saygili, M., Peters, R., \& Knebel, C. (2018). African continental free trade area: Challenges and opportunities of Tariff reductions. UNCTAD Research Paper No. 15. Retrieved November 4, 2021, from https://unctad.org/system/files/official-document/ser-rp-2017d15_en.pdf

Stewart, T. (2020). Competition regimes in the Caribbean community and Sub-Saharan Africa: A comparison. African journal of international economic law, 1, 84. Retrieved November 4, 2021, from https://www.afronomicslaw.org/journal-file/ competition-regimes-caribbean-community-and-sub-saharan-africa-comparison

Sucker, F., \& Klaaren, J. (forthcoming). Trade and competition (laws): Interrelations from a southern African perspective. In F. Sucker, \& K. Kugler (Eds.), International Economic Law from a Southern African Perspective (Chapter 14). Retrieved November 4, 2021 at https://www.researchgate.net/ publication/347453043_chapter_14_-_Sucker-Klaaren_-_Trade_and_competition__final

United Nations. (2019). Economic commission for Africa; African Union Commission; African Development Bank. Assessing regional integration in Africa ARIA IX: Next steps for the African continental free trade area. UN. ECA. Retrieved November 4, 2021, from https://www.tralac.org/documents/ resources/africa/2898-assessing-regional-integration-in-africa-ix-uneca-auc-afdb-unctad-july-2019/ file.html

United Nations Development Program. (2020). Africa's promise: The UNDP renewed strategic offer in Africa 
United States House of Representatives. (2020). Antitrust subcommittee of judiciary committee, staff report, Investigation of competition in the digital marketplace: Majority staff report and recommendations. Retrieved November 4, 2021, from https://judiciary.house.gov/uploadedfiles/competition_in_digital_markets.pdf

Vilakazi, T., Goga, S., \& Roberts, S. (Eds.). (2020). Opening The South African economy: Barriers to entry \& competition. Human Sciences Research Council

Wolf, M. (2005). Hypocrisy of the rich. Why globalization works (p. 212). Yale University Press

World Trade Organization. (1996). General agreement on trade in services. Annex on telecommunications. Retrieved November 4, 2021 from WTO.org.

World Trade Organization. (1998). Report of the working groupon the interaction between trade and competition policy to the general council WT/WGTCP/2, Dec. 8, 1998

Publisher's Note Springer Nature remains neutral with regard to jurisdictional claims in published maps and institutional affiliations. 